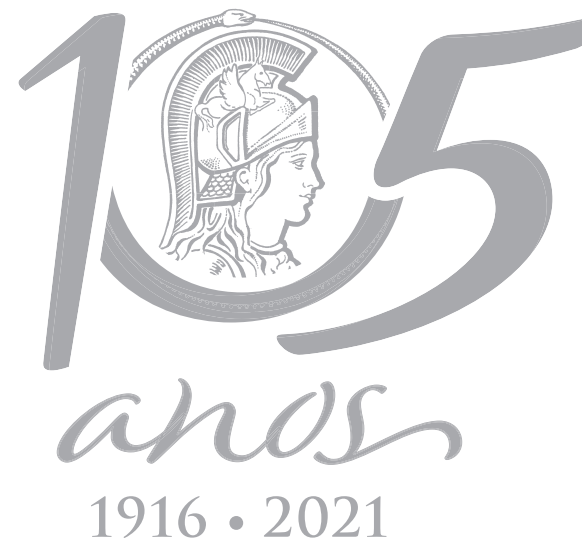

$1916 \cdot 2021$

\title{
ECOSYSTEMS
}

\section{Reproductive Biology of Astragalus argaeus (Fabaceae), a critically endangered endemic species}

\author{
BAYRAM ATASAGUN, AHMET AKSOY, ISMAIL BAYRAM GÜLLÜ \& SEVIL ALBAYRAK
}

\begin{abstract}
Astragalus argaeus is an endemic plant species that is under critical risk of extinction. Here we investigated its population census, breeding system and reproductive success to determine the main factors affecting restricted distribution of this species. According to the results from pollination experiments, A. argaeus was autogamous but benefit from the cross pollination (xenogamous) and the presence of pollinators increases fruit set. The pollen/ovule ratio of A. argaeus was calculated as 3119, which correspond to facultative xenogamy. Reproduction biology data obtained by both methods are quite compatible with each other. Pollen viability and stigma receptivity data showed that both stigma receptivity and pollen viability were high and was no temporal isolation throughout the anthesis. Seed viability of $A$. argaues was determined as $52 \%$. The low reproductive success of the species could be attributed to low seed viability and germination rates, small population size and variations in season and climate.
\end{abstract}

Key words: Astragalus argaeus, endemic, reproductive biology, conservation biology, life history.

\section{INTRODUCTION}

The breeding system is especially important in flowering plants, since it represents the only opportunity to move between specific populations by pollen and seed distribution during the life cycle for genes (Levin \& Kerster 1974). Breeding plays an essential role in finding out the genetic diversity and evolutionary dynamics within and between populations. Studies of the reproductive system have focused on measuring the frequency of outcrossing or self-fertilization in the population (Barrett 2003). Population differentiation caused by natural selection or genetic drift can be reduced by high gene flow which can increase effective population size (Slatkin 1985). Variations in gene flows of plant species ( $\mathrm{Nm}$ ) and genetic differentiation estimates generally reflect the differences in pollination and mating systems (Govindaraju 1988). Knowledge on reproduction is crucial to understand the reasons of rarity and for conservation of rare plant taxon (Kaye 1999, Ayensu 1981, Kruckeberg \& Rabinowitz 1985). Therefore, detailed information about the reproductive biology and population genetics of endangered plant taxa is necessary for development of effective conservation strategies (Allphin et al. 2005).

Turkey extends over three bio-geographical regions: Mediterranean, Anatolian, the Black Sea regions. Thanks to its location, the country has a biodiversity comparable to that of a small continent. Turkey is also the only country 
in the world under the influence of three phytogeographical regions (Euro-Siberian, IranoTuranian and Mediterranean). Turkey has nearly 12,000 natural vascular plant taxa, almost 32\% of which are endemic, and new taxa are defined each passing day (Güner et al. 2012). Most of the endemic plant taxa was assessed as threatened or endangered in Turkey (Ekim et al. 2000b). Although Turkey is quite rich in plant diversity, number of studies on reproduction biology and life history of species is highly limited. Some of these studies are as follows; Gücel \& Seçmen (2008, 2009), Seçmen et al. (2010), Trias-Blasi et al. (2016). Proper management of endangered plant species requires well-comprehension of life history features (Karron 1991).

Fabaceae family, which is one of the largest plant families on earth. It consists of approximately 27800 taxa in the World (WFO, 2021). The Astragalus (Fabaceae) L., known as milkvetch, is the largest genus of flowering plants in the world. Distributed throughout the cool to temperate arid and semiarid regions of northern hemisphere, Western North America and South America, Central Asia. Astragalus consists of about 3000 species and more than 250 sections (Podlech 1986, Podlech \& Zarre 2013, Maassoumi 1998) while few species are widespread, many species are locally endemic. These local endemic species exhibit less vigor owing to inbreeding depression and low genetic variability within populations (Karron et al. 1988, Karron 1989, Allphin et al. 2005). Considering the number of species of Astragalus in Turkey, there are 483 taxa and 63 sections with 51\% endemism (Güner et al. 2012, Karaman Erkul et al. 2014, 2016, ilçim \& Behçet 2016, Hamzaoğlu 2020). The Astragalus is widely distributed over the steppe environment of high mountains in IranoTuranian phytogeographic region of Turkey. The monotypic endemic Argaeus Bunge section has only one species, namely Astragalus argaeus Boiss. in Turkey (Chamberlain \& Mathews 1970).

A. argaeus is a perennial species, narrow endemic to Erciyes Mountain of Kayseri. It grows in small populations restricted to volcanic calcareous soils of Erciyes Mountain. This species was catalogued in "Endangered (EN)" category (Ekim et al. 2000a) and was later suggested to be included in "Critically Endangered (CR)" category by Vural \& Şapçı (2012). Despite the species status as CR, there is no study on reproductive and conservation biology of the species.

The primary objectives of the present study were (1) to update the conservation status of A. argaeus by defining its population census; (2) to investigate breeding system using both direct and indirect methods; (3) to determine the pollen viability, stigma receptivity and reproductive successes. In short, the life story of this species was investigated.

\section{MATERIALS AND METHODS}

\section{The study species}

A. argaeus is a dwarf cushion-forming scapose perennial plant composed of a much branched, woody caudex. The flowers are 11-17 mm long, pale yellow to whitish-cream. The legume is ovoid, densely covered white simple pilose and contains usually two seeds. Flowering occurs during July and August, and the fruiting occurs throughout August and September.

\section{The spatial distribution and census of the populations}

The species grows naturally on volcanic calcareous habitats of Erciyes Mountain at an altitude of between 2900-3100 m. To see whether the other populations exist in the field, the most suitable habitats for this species were visited between the years 2014-2016 during the vegetation period. 
During the site visits, distribution of plant specimens was recorded with a GPS device. The number of individuals within the populations was estimated by long line transect, which was repeated 50 times. Fifty sample areas were randomly sampled from the populations. The plants in these sample areas were counted and the average number of individuals per square meter was determined. The number of individuals in within the population was calculated by multiplying the average number of individuals per square meter by the size of the population area.

\section{Breeding System}

\section{The direct method (Pollination experiments)}

The A. argaeus pollination type was monitored for two consecutive years (2015 and 2016) during the flowering periods. The plants were randomly selected in the sites. To determine which pollination type was operating on the species, 4 different treatments were used on the flower buds of intact plants in the field (Fig. 1).

a) Self-pollination (autogamy): 10 flowers were bagged prior to anthesis and marked with black stripes;

b) Agamospermy: Anthers of 10 flowers were removed prior to anthesis and flowers were bagged with green stripes;

c) Wind pollination: Anthers of 10 flowers were removed prior to anthesis and flowers were bagged with blue stripes;

d) Controls: 10 flowers were exposed to the natural agents of pollination.

The control and treated flowers were monitored and examined for 3 weeks after treatments so as to observe the fruit/seed set. In addition, insects that visited $A$. argaeus individuals were photographed and collected for identification during the fieldwork.

\section{The indirect method (Pollen/ovule ratio)}

Flowers were used at the bud stage to determine the number of pollens and ovules. A flower was collected from 5 different plants at bud-stage. For pollen counts, an anther was crumbled over a glass slide, supplemented with couple drops of water and covered then with a lamella. Counting was performed under $10 \times 10$ light-microscope through scanning the entire preparation in a zigzag pattern. Pollens of 25 anthers were counted and average of them was taken to get average number of pollens produced by a single anther. The ovules were counted in five flowers. The pollen/ovule ratio was calculated as the total number of pollen grains produced by a flower divided by the total number of ovules per flower according to Cruden (1977).

\section{Pollen viability and stigma receptivity}

For pollen viability and stigma receptivity, 5 plants and some inflorescences over 5 plants were marked at bud-stage of flowers. From the day of making, marked plants were monitored for 7 days and opened flowers were recorded. At the end of $7^{\text {th }}$ day, inflorescences were harvested from each plant. They were placed into small bottles and instantly transported to laboratory in iceboxes. They were grouped 3 days before blooming, at the day of blooming and 3 days after blooming. In the laboratory while the examination each flower was dissected and the stigmas and anthers were removed.

MTT (2.5-diphenyl tetrazolium bromide blue) method was used to test pollen viability. In this method, the color of pollen grains turns into dark purple or black in the presence of dehydrogenase enzyme. The stained pollen grains were considered as viable; while noncolored pollen grains were accepted as unviable. The anther of each flower was crumbled over a glass slide. Then, $1 \%$ MTT solution was mixed with $5 \%$ sucrose solution and the solution 

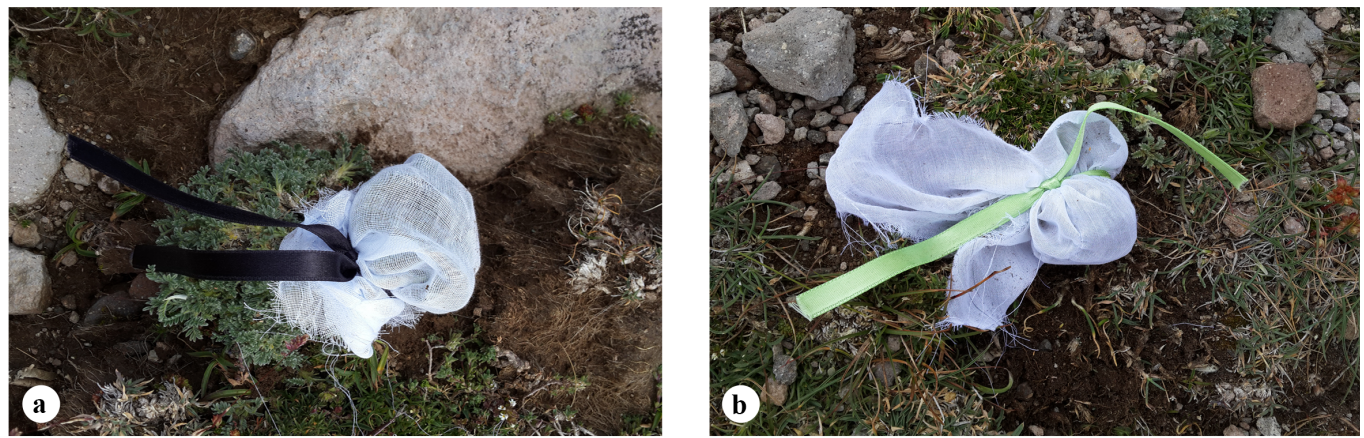

Figure 1.

Pollination experiments of A. argaeus (a. autogamy, b. Agamospermy, c. Wind pollination, $\mathrm{d}$. Control).
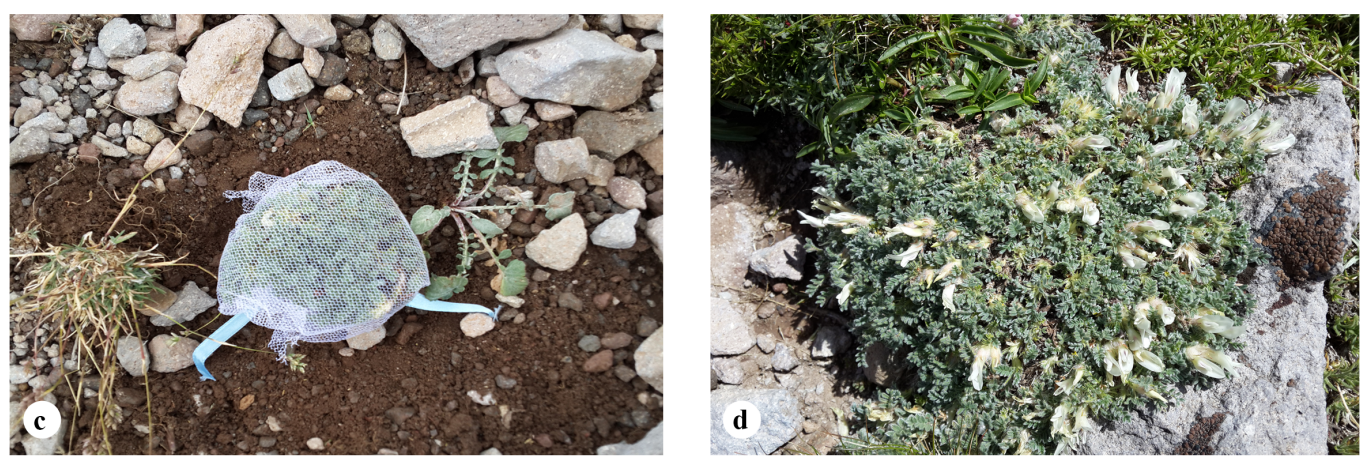

was dropped directly over the pollen grains. The pollen preparations were incubated for approximately an hour at $35-37{ }^{\circ} \mathrm{C}$. Leica DM750 light microscope was used to examine pollen preparations. A total of 500 randomly selected viable and non-viable pollen grains were counted in 5 replicates and the percentage of viability was calculated daily (Firmage \& Dafni 2001).

Macherey-Nagel Peroxtesmo Ko peroxidase test paper was used for stigma receptivity. One $(15 \times 15 \mathrm{~mm})$ Peroxtesmo Ko paper was soaked into $1 \mathrm{ml}$ distilled water. A droplet of solution was dropped directly onto the stigma. The color of stigma was very dark or blue in the presence of peroxidase and those stigmas were considered as receptive (Dafni \& Maués 1998). The stigma slides were investigated under stereomicroscope. Each experiment was repeated three times, thus a total of 21 stigmas were used in the experiments.

\section{Seed viability}

Tetrazolium test was used to determine the viability of A. argaeus seeds. Because legume members have a thick seed coat, seeds were subjected to concentrated $\mathrm{H}_{2} \mathrm{SO}_{4}$ treatments for 3-4 min in order to thin the coats. A total of 75 randomly selected seeds were soaked into water overnight. Then, seed coats were peeled and embryos were treated with $0.1 \%$ tetrazolium chloride for $24 \mathrm{~h}$ at room temperature. While the stained embryos were categorized as viable, the unstained ones were categorized as inviable (Moore 1985).

\section{Reproductive success}

Studies to determine reproductive success were carried out with direct field observations between the years 2014-2016. For that purpose, the mean number of flowers per plant, the mean number of ovules per flower, the mean number of fruits per plant, the mean number of seeds per fruit was calculated. The means, standard 
deviations and minimum-maximum values of all data were determined. Potential seed count (PSC) was calculated by multiplying the mean number of flowers per plant (NFP) by the mean number of ovules per flower (NOF). [(PSC) = NFP $\times$ NOF]. Actual seed count (NAS) was estimated by multiplying the mean number of fruits (NF) per plant by the mean number of seeds per fruit (NS) in natural conditions $[(N A S)=N F \times$ NS]. The percentage of reproductive success was estimated with the equation of NAS $\times 100 /$ PSC (Subaşı \& Güvensen 2011).

\section{RESULTS}

\section{The spatial distribution and census of the populations}

During the field research, another population of Astragalus argaeus which is known to be recorded in three populations was found in Erciyes Mountain. The region includes a classic metapopulation with four known populations. These populations are Çobanini population, which covers $5949 \mathrm{~m}^{2}$ and includes 594 individuals, Sütdonduran (East) population (2656 m², 297 individuals), Sütdonduran (West) population (5071 $\mathrm{m}^{2}, 676$ individuals) and Ottoman (new) population (17149 m², 1136 individuals). The total area of $A$. argeus was estimated to be $30825 \mathrm{~m}^{2}$ and the total number of individuals was calculated as 2703 .

\section{Pollination experiments}

As a result of pollination experiments, fruit set was observed at 6 of 10 bagged flowers for self-pollination and 8 of 10 untreated flower for control. However, fruit set was not observed in flowers bagged for agamospermy and wind pollination. According to the observations, it was determined that the most active pollinators to the flowers were bees (Apis mellifera, Bombus sp.).

\section{Pollen/ovule ratio}

The average number of pollens produced by an anther in A. argaeus was determined as 1247.6. Because a flower has 10 stamens, the number of pollens produced by a flower was calculated as 12476. To find the number of pollens per ovule; the total number of pollens produced by a flower was divided by the number of ovules in a flower (a flower contains 4 ovules). P/O ratio of A. argaeus was calculated as 3119. The log of this number is 3.49. The probable reproductive system was determined as facultative xenogamy from the pollen/ovule ratio based on Cruden's scale (Cruden 1977).

\section{Pollen viability and stigma receptivity}

The mean pollen viability was $17 \% 3$ days before the blooming of the flowers, $38 \% 2$ days before the blooming, 60\% 1 day before the blooming, $77 \%$ on the day of full-bloom, 57\% 1 day after the blooming, 43\% 2 days after the blooming, 24\% 3 days after the blooming.

According to peroxidase test paper results, stigma receptivity increased one day before the blooming and reached to a peak on the day of full-bloom. The stigma receptivity gradually decreased later on (Fig. 2).

\section{Seed viability}

The tetrazolium staining results showed that 39 seeds were stained red or dark red, while 36 seeds were not stained. The seed viability was calculated as $52 \% \pm 8$.

\section{Reproductive success}

According to the reproductive success studies, the mean number of flowers per plant in $A$. argaeus was 32.03, the mean number of ovules per flower was 3.26, the mean number of fruits per plant was 28 , the mean number of seeds per fruit was 1.9. Using these data, it was calculated that the potential seed count (PSC) was 104.29 

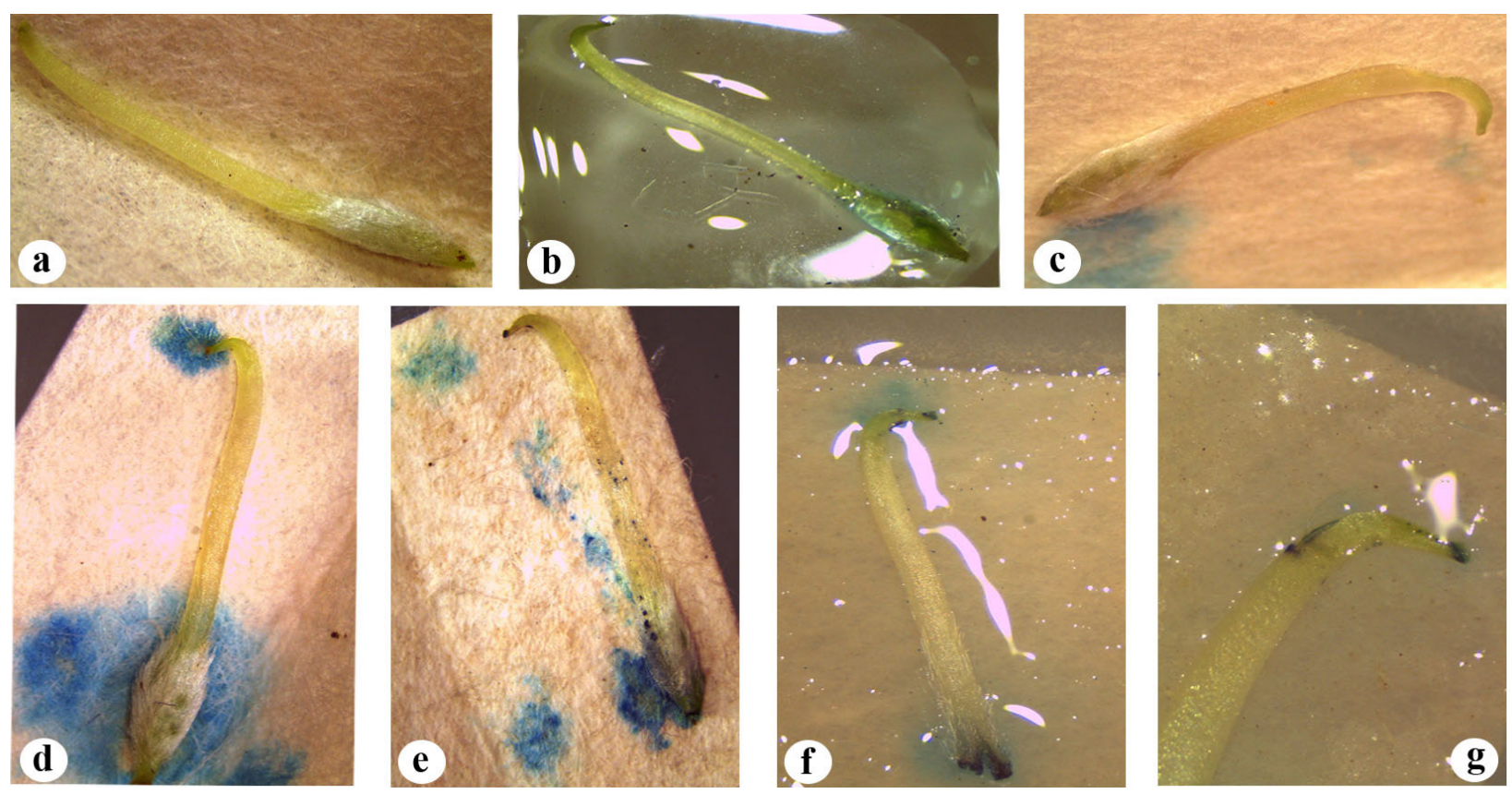

Figure 2. The stigmas of $A$. argaeus treated with perex test (a. 3 days before the blooming of the flowers, b. 2 days before the blooming of the flowers, c. 1 days before the blooming of the flowers d. the day of full-bloom e. 1 day after the blooming f. 2 day after the blooming $\mathrm{g} .3$ day after the blooming).

and the actual seed count (NAS) was 53.2. The percentage of reproductive success for a plant was estimated as 51.01 according to equation of NAS $\times 100 /$ PSC (Table I).

\section{DISCUSSION}

For the success of conservation efforts and to assess permanence of different plant populations, demography, reproductive biology and life history features should be well-comprehended in an integrated fashion and relevant strategies should be developed accordingly (Ohara et al. 2006). The endangered species keep moving to extinction unless the factors threating the existence of these species were identified and rehabilitated. Knowledge on especially the future of narrow-spread rare or endemic species plays a great role in conservation and persistence of the species.

A. argaeus was not found in a single locality as reported in the study Vural \& Şapçı (2012).
Aksoy et al. (2012) reported three different localities for the distribution of $A$. argaeus in Erciyes Mountain. Besides these three localities, another locality was identified in present study for the distribution of $A$. argaeus in Erciyes Mountain. These 4 localities have an area of $30825 \mathrm{~m}^{2}$ with 2703 individuals.

Astragalus is an enormous genus with a cosmopolitan distribution, but knowledge about their reproductive biology is quite limited. The reproductive biologies of Astragalus range from self-incompatible to self-compatible, occasionally xenogamous to obligately so. This wide range of reproductive biologies in the genus makes it suspicious to estimate the breeding biology of Astragalus species (Watrous \& Cane 2011). In this study, it was observed that the flowers which were left open to pollination, formed more fruits than the flowers that were closed for self-pollination. It was also determined that $A$. argaeus was selfcompatible; but benefit substantially from the 
Table I. Values of some features of A. argaeus.

\begin{tabular}{|c|c|c|c|}
\hline & Mean & SD. & Min.-Max. \\
\hline $\begin{array}{c}\text { Flower number per } \\
\text { plant }\end{array}$ & 32.03 & 13.61 & $8-68$ \\
\hline $\begin{array}{c}\text { Fruit number per plant } \\
\begin{array}{c}\text { Ovule number per } \\
\text { flower }\end{array}\end{array}$ & 28 & 13.62 & $3-58$ \\
\hline $\begin{array}{c}\text { Seed number per fruit } \\
\text { Fruit set (\%) }\end{array}$ & 1.9 & 1.06 & $1-4$ \\
\hline $\begin{array}{c}\text { The potential seed } \\
\text { count (PSC) }\end{array}$ & 87.42 \\
\hline $\begin{array}{c}\text { The actual seed count } \\
\text { (NAS) }\end{array}$ & 104.29 \\
\hline $\begin{array}{c}\text { Reproductive success } \\
\text { for a plant }\end{array}$ & \multicolumn{3}{|c|}{53.2} \\
\hline
\end{tabular}

cross-pollination (xenogamous) facilitated by bee visitation. This combination of selfcompatibility while supporting outcrossing is generally classified as a "mixed mating system" when choosing external fertility (Neal \& Anderson 2005). According to the observations, the most common pollinators of $A$. argaeus were bumble bees and honeybees. It was determined that $A$. argaeus should be cross-pollinated with bees to produce abundant seeds.

The reproductive biologies of papilionoid legumes rang from cleistogamous to obligately xenogamous (Arroyo 1981). Similar present findings, Watrous \& Cane (2011) studied breeding biology of $A$. filipes and reported that the species was weakly self-compatible but cross-pollination significantly increased fruit and seed set. Green \& Bohart (1975) found that $A$. cibaricus and $A$. utahensis were strongly allogamous and they were dependent on insects for pollination. Kaye (1999) studied the reproductive ecology of an endemic plant Astragalus australis var. olympicus and reported that plants were typically outcrossed, but genetically self-compatible and bumble bees and solitary bees were the dominant flower visitors. Tanner et al. (2013) in their study to determine the pollination biology of Astragalus phoenix, reported that $A$. phoenix did not set fruit in the absence of pollinator. For this reason, it was determined that the species was obligate xenogamous and Apis mellifera and Anthophora porterae were the most likely pollinators. Present findings well comply with those earlier findings. Stebbins (1957) suggested that there was a high probability of self- compatibility in rare plants. When the population of the plant is reduced or the gene flow decreases, genetic load can be widely removed, such a case then decrease inbreeding depression and increase self-compatibility (Kaye 1999, Lande \& Schemske 1985). Thus, self-compatibility in A. argaeus was complying with the theory of small populations.

Pollen-ovule ratio ( $\mathrm{P} / \mathrm{O}$ 's) is a method used to investigate the breeding system in plants. This method with experimental emphasis on the family of Fabaceae was developed by Cruden (1977). Cruden stated that the autogamous flowers had lower P/O's than xenogamous flowers and cleistogamous flowers should have the lowest $\mathrm{P} / \mathrm{O}$ 's. The $\mathrm{P} / \mathrm{O}$ ratio of $A$. argaeus was determined as 3119. Such a ratio indicated that $A$. argaeus corresponded to facultative xenogamy as presented by Cruden (1977). Present data for breeding systems were quite compatible with each other for A. argaeus.

The pollen viability and stigma receptivity are significant indicators of flower maturity and reproductive success (Dafni \& Maués 1998). It was observed that pollens had the greatest viability on the day blooming and this viability was gradually decreased in the other days. Present stigma receptivity results showed that stigma receptivity began to develop one day before the blooming and reached to the maximum level on the day of full-bloom, then gradually decreased later on. Both the stigma 
receptivity and the pollen viability were high and there was no temporal isolation between them throughout the anthesis. Galloni et al. (2007) stated that stigmas were not receptive when the flower bud had a closed corolla and stigmas became receptive when the anthers started to dehiscent in Astragalus glycyphyllos. In a study conducted on Salvia smyrnaeae, it was determined that stigma enzyme activity was less in young flowers and higher in mature flowers; pollen viability was found to be higher in young flowers and lower in mature flowers. Therefore, it was determined that S. smyrnaea flowers were protandric-hermaphrodite (Subaşı \& Güvensen 2011). Studies on the reproductive biology of Erodium somanum (Oskay 2017), stressed that pollen viability and stigma receptivity were high and synchronous during anthesis.

The sustainability of plant populations depends on the germination response of plant seeds under various environmental conditions. Seed germination studies are key components of conservation programs since they can be used in the recovery and management of endangered species (Ortega-Baes \& RojasAréchiga 2007). Like many Astragalus species, A. argaeus seed have impermeable and hard seed coat, therefore scarification is required to break the dormancy before germination (Baskin \& Baskin 2001). To break the dormancy and increase germination, plant growth regulators (such as $\mathrm{GA}_{3}$ ), various chemicals (sulfuric acid, nitric acid, etc.), mechanical scarification have been recommended (Keshtkar et al. 2010).

Seed viability tests were conducted to gather information about the germination potential of seeds. Seed viability of A. argaeus was found to be low (52\%). Considering the germination success together with seed viability, it was concluded that germination problem of endangered species had an effect on decreasing populations.
Reproductive success is crucial for fitness and long-term survival of species and conservation of rare plant taxa (Harper 1977). Any problems in life history of a plant may restrict reproductive ability of that plant. Such problems in long run may contribute to rarity and prevent conservation of the species (Kaye 1999). The mean percentage of fruit set was determined as $87.4 \%$. Such a value may be sufficient for the population. Thirty-two fertilized flowers potentially have 104 seeds, but 53 seeds were formed by these flowers. The rate of reproductive success was determined at moderate level with $51 \%$. However, when these data are evaluated with seed viability test (52\%), it can be seen that 27 of 53 seeds could germinate. In this case, the rate of seeds that can be germinated per plant decreased to $26 \%$. The number of seeds able to form mature individuals are continuously decreasing since the number of seeds able to find a proper place to germinate, number of germinated seeds able to adapt the environmental conditions and the number of seedlings able to survive without grazed by the animals are decreasing. The decline in seed production is one of the great threats to plant life history and may raise the likelihood of extinction of populations and species (Ohara et al. 2006). Consequently, reproductive success of $A$. argaeus was low. The low reproductive success was not associated with pollen viability and stigma receptivity because both were found to be high and synchronous. Low reproductive success may be attributed to low germination rates, small population size and variations in seasonal and climate parameters.

Astragalus argaeus was first catalogued in the category as "Endangered"(Ekim et al. 2000a). Then, Vural \& Şapçı (2012) proposed the conservation status of the species as CR A1a; B2ab(iii). With regard to the findings obtained from the field studies and based on the IUCN 
(2016), it was suggested in this study that A. argaeus should be catalogued as Critically Endangered [CR B2b(i,ii,iii)c(i,ii)] due to the area of occupancy less than $10 \mathrm{~km}^{2}$, decline and extreme fluctuations in distribution and habitat areas.

In conclusion, A. argaeus is under critical risk of extinction due to habitat destruction, low number of seeds able to germinate, overgrazing and tourism activities of the region. For the success of conservation biology studies on endangered species, life history of these species should be identified.

\section{Acknowledgments}

Authors are grateful to Erciyes University Research Fund for the financial support provided for this project (project no: FDK-2015-5693).

\section{REFERENCES}

AKSOY A, ATASAGUN B \& MARTIN E. 2012. Conservation status and autecological characters of Astragalus argaeus Boiss. In: International Symposium on Biology of Rare and Endemic Plant Species (BIORARE), 23-27 April 2012 2012 Fethiye/Turkey, p. 31.

ALLPHIN L, BRIAN N \& MATHESON T. 2005. Reproductive success and genetic divergence among varieties of the rare and endangered Astragalus cremnophylax (Fabaceae) from Arizona, USA. Conserv Genet 6: 803-821.

ARROYO MTK. 1981. Breeding systems and pollination biology in Leguminosae. Advances in legume systematics: 723-769.

AYENSU ES. 1981. Assessment of threatened plant species in the United States. Biological aspects of rare plant conservation.

BARRETT SCH. 2003. Mating strategies in flowering plants: the outcrossing-selfing paradigm and beyond. Phil Transac Royal Society B: Biol Sci 358: 991-1004.

BASKIN CC \& BASKIN JM 2001. Seeds: Ecology, Biogeography, And, Evolution of Dormancy and Germination. Elsevier Science.

CHAMBERLAIN D \& MATHEWS M 1970. Astragalus L. In: Davis $P(E d)$, Flora of Turkey and the East Aegean Islands, Edinburgh, UK: Edinburgh University Press, p. 49-254.
CRUDEN RW. 1977. Pollen-Ovule Ratios: A Conservative Indicator of Breeding Systems in Flowering Plants. Evolution 31: 32-46.

DAFNI A \& MAUÉS MM. 1998. A rapid and simple procedure to determine stigma receptivity. Sex Plant Reprod 11: 177-180.

EKIM T, KOYUNCU M, VURAL M, DUMAN H, AYTAÇ Z \& ADGÜZEL N. 2000a. Türkiye Bitkileri Kırmızı Kitabı, Eğrelti ve Tohumlu Bitkiler (Red Data Book of Turkish Plants. Pteridophyta and Spermatophyta). Barışçan Ofset.

EKIM T, KOYUNCU M, VURAL M, DUMAN H, AYTAÇ Z \& ADGÜZEL N 2000b. Türkiye Bitkileri Kırmızı Kitabı, Türkiye Tabiatını Koruma Derneği ve Van 100. Yıl Üniv, Ankara.

FIRMAGE DH \& DAFNI A. 2001. Field tests for pollen viability: a comparative approach. Acta Horticulturae 561: 87-94.

GALLONI M, PODDA L, VIVARELLI D \& CRISTOFOLINI G. 2007. Pollen presentation, pollen-ovule ratios, and other reproductive traits in Mediterranean Legumes (Fam. Fabaceae - Subfam. Faboideae). Plant Syst Evol 266: 147-164.

GOVINDARAJU DR. 1988. A note on the relationship between outcrossing rate and gene flow in plants. Heredity 61: 401.

GREEN TW \& BOHART GE. 1975. The Pollination Ecology of Astragalus cibarius and Astragalus utahensis (Leguminosae). Am J Bot 62: 379-386.

GÜCEL S \& SEÇMEN Ö. 2008. Reproductive Biology of Subalpin Endemic Minuartia nifensis Mc Neill (Caryophyllaceae) From West Anatolia, Turkey. Biodicon 1(1): 66-74.

GÜCEL S \& SEÇMEN Ö. 2009. Conservation biology of Asperula daphneola (Rubiaceae) in Western Turkey. Turk J Bot 33: 257-262.

GÜNER A, ASLAN S, EKIM T, VURAL M \& BABAÇ M 2012. Türkiye Bitkileri Listesi (Damarlı Bitkiler). İstanbul, Turkey: Nezahat Gökyiğit Botanic Garden and Floristics Research Society.

HAMZAOĞLU E 2020. Astragalus askaleensis (sect. Adiaspastus, Fabaceae), a new species from Turkey. Spec Habit 1(2): 114-123.

HARPER JL 1977. Population biology of plants. London ; New York: Academic Press, 892 p.

IUCN. 2016. Standards and Petitions Subcommittee. Guidelines for Using the IUCN Red List Categories and Criteria. Version 12. 
ILÇIM A \& BEHÇET L. 2016. Astragalus topalanense (Fabaceae), a new species from Turkey. Turk J Bot 40: 74-80.

KARAMAN ERKUL S, BAGHERI A, MAASSOUMI AA \& RAHIMINEJAD MR. 2014. Notes on Astragalus sect. Hymenostegis (Fabaceae) from Turkey. Turk J Bot: 39: 205-207.

KARAMAN ERKUL S, AYTAÇ Z \& EKICI M. 2016. Synopsis of the sect. Hymenocoleus, sect. Hymenostegis, and sect. Macrophyllium belonging to Astragalus (Fabaceae) in Turkey. Turk J Bot 40(4): 412-418.

KARRON JD. 1989. Breeding Systems and Levels of Inbreeding Depression in Geographically Restricted and Widespread Species of Astragalus (Fabaceae). Am J Bot 76: 331-340.

KARRON JD. 1991. Breeding Systems in Rare Plant Species. Genetics and conservation of rare plants: 87.

KARRON JD, LINHART YB, CHAULK CA \& ROBERTSON CA. 1988. Genetic Structure of Populations of Geographically Restricted and Widespread Species of Astragalus (Fabaceae). Am J Bo 75: 1114-1119.

KAYE TN. 1999. From flowering to dispersal: reproductive ecology of an endemic plant, Astragalus australis var. olympicus (Fabaceae). Am J Bot 86: 1248-1256.

KESHTKAR A, KESHTKAR H, RAZAVI SM \& DALFARDI S 2010. Methods to break seed dormancy of Astragalus cyclophyllon. n. 7.

KRUCKEBERG AR \& RABINOWITZ D. 1985. Biological aspects of endemism in higher plants. Ann Rev Ecol Systemat 16: 447-479.

LANDE R \& SCHEMSKE DW. 1985. The evolution of selffertilization and inbreeding depression in plants. I. Genetic models. Evolution 39: 24-40.

LEVIN AD \& KERSTER WH. 1974. Gene Flow in Seed Plants. J Evol Biol 7: 139-220.

MAASSOUMI AA. 1998. Astragalus in the Old World: checklist. Tehran, Iran: Research Institute of Forests and Rangelands.

MOORE R. 1985. Handbook on Tetrazolium Testing, International Seed Testing Association: Zurich, Switzerland.

NEAL PR \& ANDERSON GJ. 2005. Are 'mating systems' 'breeding systems' of inconsistent and confusing terminology in plant reproductive biology? or is it the other way around? Plant Systemat Evol 250: 173-185.

OHARA M, TOMIMATSU H, TAKADA T \& KAWANO S. 2006. Importance of life history studies for conservation of fragmented populations: A case study of the understory herb, Trillium camschatcense. Plant Spec Biol 21: 1-12.

ORTEGA-BAES P \& ROJAS-ARÉCHIGA M. 2007. Seed germination of Trichocereus terscheckii (Cactaceae): Light, temperature and gibberellic acid effects. J Arid Environ 69: 169-176.

OSKAY D 2017. Reproductive biology of the critically endangered endemic plant Erodium somanum in Turkey. Turk J Bot 41: 171-179.

PODLECH D. 1986. Taxonomic and phytogeographical problems in Astragalus of the Old World and SouthWest Asia. Proc R Soc London Ser B: Biol Sci 89: 37-43.

PODLECH D \& ZARRE S 2013. Taxonomic Revision of the Genus Astragalus L. (Leguminosae) in the Old World. $n$. II, Vienna, Austria: Naturhistorischen Museum Wien.

SEÇMEN Ö, GÜVENSEN A, ŞENOL SG \& GÜCEL S. 2010. Pollination Behaviour of Linum aretioides Boiss. (Linaceae) and Its Relations with Air Temperature and Humidity. Turkish Journal of Botany 34: 355-365.

SLATKIN M. 1985. Gene Flow in Natural Populations. Ann Rev Ecol Systemat 16: 393-430.

STEBBINS GL. 1957. Self Fertilization and Population Variability in the Higher Plants. Amer Natural 91: 337-354.

SUBAŞI Ü \& GÜVENSEN A. 2011. Breeding systems and reproductive success on Salvia smyrnaea. Turk J Bot 35: 681-687.

TANNER AD, CLARK C \& PITTS J. 2013. Pollination Biology of Astragalus phoenix (Fabaceae) with Notes on the Natural History of its Pollinator, Anthophora porterae (Hymenoptera: Apidae). West North Amer Natural 73: 373-381.

TRIAS-BLASI A, GÜCEL S \& ÖZDEN Ö. 2016. Current Distribution and Conservation Status Reassessment of The Cyprus Tulip (Tulipa cypria: Liliaceae), New Data From Northern Cyprus. Plant Biosyst 151(3): 394-402.

VURAL C \& ŞAPÇI H. 2012. A single locality, endemic species, Astragalus argaeus (Fabaceae). Kew Bull 67: 89-92.

WATROUS K \& CANE J. 2011. Breeding Biology of the Threadstalk Milkvetch, Astragalus filipes (Fabaceae), with a Review of the Genus. Am Midl Nat 165: 225-240.

WFO - WORLD FLORA ONLINE. 2021. Fabaceae Juss. Published on the Internet; http://www.worldfloraonline.org/taxon/ wfo-7000000323. Accessed on: 25 Mar 2021. 


\section{How to cite}

ATASAGUN B, AKSOY A, GÜLLÜ iB \& ALBAYRAK S. 2021. Reproductive Biology of Astragalus argaeus (Fabaceae), a critically endangered endemic species. An Acad Bras Cienc 93: e20201613. DOI 10.1590/00013765202120201613.

Manuscript received on October 15, 2020;

accepted for publication on April 8, 2021

\section{BAYRAM ATASAGUN ${ }^{1}$}

https://orcid.org/0000-0003-0097-5695

\section{AHMET AKSOY ${ }^{2}$}

https://orcid.org/0000-0002-9696-7122

\section{ISMAIL BAYRAM GÜLLÜ ${ }^{3}$}

https://orcid.org/0000-0003-4198-3886

\section{SEVIL ALBAYRAK ${ }^{4}$}

https://orcid.org/0000-0002-0253-3746

${ }^{1}$ Selçuk University, Vocational School of Health Services, Akademi District, Yeni İstanbul Street, 42130, Konya, Turkey

${ }^{2}$ Akdeniz University, Department of Biology, Science Faculty, Dumlupınar Boulevard Campus, 07058, Antalya, Turkey

${ }^{3}$ Erciyes University, Graduate School of Natural Applied Sciences, Yenidoğan District, Turhan

Baytop Street, 38030, Kayseri, Turkey

${ }^{4}$ Erciyes University, Department of Biology, Science Faculty, Yenidoğan District, Turhan Baytop Street, 38039, Kayseri, Turkey

Correspondence to: Bayram Atasagun

E-mail:byrmatsgn@gmail.com

\section{Author contributions}

This research was derived from the Ph. D. thesis of the first author. The main idea of the article came from supervisors Ahmet Aksoy and Sevil Albayrak. Thus, fieldwork, writing, collection, description and interpretation of data were conducted by Bayram Atasagun. Ismail Bayram Güllü contributed to the fieldwork, collection and identification studies. All authors discussed the results and contributed to the final manuscript and revisions.

\section{(cc) BY}

